Review Article

\title{
Hepatitis C Worldwide and in Brazil: Silent Epidemic - Data on Disease including Incidence, Transmission, Prevention, and Treatment
}

\author{
Iara Fabricia Kretzer, ${ }^{1}$ Andrea do Livramento, ${ }^{1}$ Joel da Cunha, ${ }^{2}$ Sabrina Gonçalves, ${ }^{1}$ \\ Iraci Tosin, ${ }^{3}$ Celso Spada, ${ }^{1}$ and Aricio Treitinger ${ }^{1}$ \\ ${ }^{1}$ Clinical Analysis Department, Health Sciences Center, Federal University of Santa Catarina, \\ 88010-970 Florianópolis, SC, Brazil \\ ${ }^{2}$ Laboratory of Genetics and Molecular Hematology, University of São Paulo Medical School, HCFMUSP, \\ 05403-010 São Paulo, SP, Brazil \\ ${ }^{3}$ Department of Microbiology, Immunology and Parasitology, Centre of Biological Sciences, \\ Federal University of Santa Catarina, 88040-900 Florianópolis, SC, Brazil \\ Correspondence should be addressed to Iara Fabricia Kretzer; iarakretzer@usp.br
}

Received 5 February 2014; Accepted 16 May 2014; Published 10 June 2014

Academic Editor: Chien-Hung Chen

Copyright ( 2014 Iara Fabricia Kretzer et al. This is an open access article distributed under the Creative Commons Attribution License, which permits unrestricted use, distribution, and reproduction in any medium, provided the original work is properly cited.

\begin{abstract}
Hepatitis C virus (HCV) is endemic worldwide and according to the World Health Organization (WHO), there are about 150 million chronic carriers worldwide. The infection is a leading cause of liver diseases like cirrhosis and hepatocellular carcinoma (HCC); thus, HCV infection constitutes a critical public health problem. There are increasing efforts worldwide in order to reduce the global impact of hepatitis $\mathrm{C}$ through the implementation of programmatic actions that may increase the awareness of viral hepatitis and also improve surveillance, prevention, and treatment. In Brazil, about 1,5 million people have been chronically infected with HCV. The country has a vast territory with uneven population density, and hepatitis $\mathrm{C}$ incidence rates are variable with the majority of cases concentrated in the most populated areas. Currently, the main priorities of Brazilian Ministry of Health's strategies for viral hepatitis management include the prevention and early diagnosis of viral hepatitis infections; strengthening of the healthcare network and lines of treatment for sexually transmitted diseases, viral hepatitis, and AIDS; improvement and development of surveillance, information, and research; and promotion of universal access to medication. This review aims to summarize the available data on hepatitis $\mathrm{C}$ epidemiology and current status of efforts in prevention and infection control around the world and in Brazil.
\end{abstract}

\section{Introduction}

Hepatitis $\mathrm{C}$, a liver disease caused by the hepatitis $\mathrm{C}$ virus (HCV), can array in severity from a mild illness, lasting a few weeks, to a serious condition that can lead to chronic liver disease, end-stage cirrhosis, and liver cancer. Worldwide, it is estimated that 350,000 people die every year from complications of hepatitis $\mathrm{C}$ disease [1].

The hepatitis $C$ virus is transmitted through contact with infectious blood. There are defined risk factors for hepatitis C virus infection, such as transfusions of HCV-infected blood, contaminated injections during medical procedures, and injection drug use. However, the risk for HCV transmission by sexual or interfamilial contact is not well established [1-3].

According to the World Health Organization (WHO), viral hepatitis is not being addressed seriously, since the early stages of the disease are silent and because of the insidious way in which chronic liver disease is caused. Many $\mathrm{HCV}$-infected patients are unaware of their disease, and the number of people who have been infected with this virus might be underestimated. Therefore, morbidity and mortality related to hepatitis $\mathrm{C}$ are likely to increase over 
TABLE 1: Worldwide prevalence of hepatitis $C$ virus.

\begin{tabular}{|c|c|}
\hline Region & Prevalence of HCV \\
\hline \multicolumn{2}{|l|}{ Africa $[9,10]$} \\
\hline Sub-Saharan Africa & $2.2 \%(0.1 \%-13.8 \%)$ \\
\hline Central Africa & $6 \%$ \\
\hline West Africa & $2.4 \%$ \\
\hline Southern and East Africa & $1.6 \%$ \\
\hline \multicolumn{2}{|l|}{ Americas $[11-13,15]$} \\
\hline \multicolumn{2}{|l|}{ North America } \\
\hline Canada & $0.7 \%$ \\
\hline United States & $1.3 \%$ \\
\hline \multicolumn{2}{|l|}{ Latin America } \\
\hline Argentina, Brazil, Mexico, Puerto Rico, Peru, and Venezuela & $1.4-2.5 \%$ \\
\hline \multicolumn{2}{|l|}{ Asia and Oceania $[2,16,22-27]$} \\
\hline \multicolumn{2}{|l|}{ South Asia } \\
\hline India & $3.4 \%$ \\
\hline \multicolumn{2}{|l|}{ Southeast Asia } \\
\hline Vietnam & $2-2.9 \%$ \\
\hline \multicolumn{2}{|l|}{ East Asia } \\
\hline Taiwan & $4.4 \%$ \\
\hline China & $1-1.9 \%$ \\
\hline Australasia (Australia and New Zealand) & $2.7 \%$ \\
\hline Melanesia,Micronesia, and Polynesia regions & $2.6 \%$ \\
\hline \multicolumn{2}{|l|}{ Eastern Mediterranean $[10,16,17]$} \\
\hline Egypt & $15 \%$ \\
\hline Pakistan & $4.9 \%$ \\
\hline \multicolumn{2}{|l|}{ Europe [21] } \\
\hline \multicolumn{2}{|l|}{ Central Europe } \\
\hline Czech Republic, Poland, Romania, and Hungary & $\leq 0.5 \%$ \\
\hline Romania & $\geq 3 \%$ \\
\hline \multicolumn{2}{|l|}{ Western Europe } \\
\hline France, Germany, Greece, Italy, Norway, Portugal, Spain, Sweden, Switzerland, and UK & $\leq 0.5 \%$ \\
\hline Rural areas in Greece and in Italy & $\geq 3 \%$ \\
\hline \multicolumn{2}{|l|}{ Eastern Europe } \\
\hline Russia & $\leq 0.5 \%$ \\
\hline Parts of Russia & $\geq 3 \%$ \\
\hline
\end{tabular}

the next years [2]. In this review the aim is to present data regarding incidence, transmission, prevention, and treatment of hepatitis C around the world and in Brazil.

\section{Worldwide Epidemiology of HCV}

$\mathrm{HCV}$ is endemic worldwide and there is a large degree of geographic variability in its distribution [7]. According to WHO, there are about 150 million chronic carriers worldwide and 3 to 4 million people are infected annually [1]. Worldwide, the prevalence of $\mathrm{HCV}$ infection is estimated to be highest in Middle East and also in Africa and lowest in much of Europe and the Americas [8].

Table 1 summarizes the prevalence of HCV infection in different regions of the world. It is shown that, in Africa, the greatest prevalence occurs in Central Africa, followed by the West Africa, Sub-Saharan Africa, and by the lower prevalence estimate found in Southern and East Africa $[9,10]$.

In the region of the Americas, North America countries such as Canada and the United States present low HCV prevalence rates [11-13]. Regarding Latin America, the presence of poorly designed studies and the regional diversity of social, economic, cultural, and environmental factors are illustrated in heterogeneous HCV prevalence data that can occasionally be dissimilar within the same country [14]. Between 7 and 9 million adults are estimated to be anti-HCV positive in Latin America and the Caribbean countries, and as those individuals were exposed to HCV, they could contract chronic infection $[2,15]$.

An estimated 17 million people in the Eastern Mediterranean region suffer from chronic $\mathrm{HCV}$ infection and approximately 800.000 people are infected with $\mathrm{HCV}$ 
TABle 2: Hepatitis C confirmed cases in Brazil according to the Ministry of Health [5].

\begin{tabular}{lcccccccccccccc}
\hline \multirow{2}{*}{ Region } & \multicolumn{1}{c}{} & \multicolumn{10}{c}{ Number of cases among the years } \\
& 1999 & 2000 & 2001 & 2002 & 2003 & 2004 & 2005 & 2006 & 2007 & 2008 & 2009 & 2010 & 2011 & $1999-2011$ \\
\hline Brazil & 188 & 309 & 632 & 2,031 & 4,021 & 7,135 & 8,572 & 9,280 & 9,517 & 9,936 & 10,534 & 10,321 & 9,565 & 82,041 \\
North & 2 & 30 & 19 & 34 & 70 & 68 & 128 & 100 & 226 & 268 & 274 & 230 & 195 & 1,644 \\
Northeast & 1 & 0 & 6 & 34 & 106 & 208 & 383 & 426 & 382 & 549 & 671 & 637 & 728 & 4,131 \\
Southeast & 110 & 166 & 363 & 1,423 & 2,791 & 5,126 & 6,073 & 6,600 & 6,430 & 6,571 & 7,095 & 6,528 & 5,946 & 55,222 \\
South & 72 & 111 & 223 & 400 & 910 & 1,530 & 1,743 & 1,924 & 2,105 & 2,248 & 2,143 & 2,561 & 2,337 & 18,307 \\
Central-west & 3 & 2 & 21 & 140 & 144 & 203 & 245 & 230 & 374 & 300 & 351 & 365 & 359 & 2,737 \\
\hline
\end{tabular}

annually [2], and Egypt is believed to have one of the highest rates of hepatitis $C$ in the world $[16,17]$. In this case, the main reason for the high prevalence rates that reach 20 $30 \%$ in young male adults was the mass programmes for the treatment of endemic schistosomiasis that frequently used unsterilized needles [18, 19].

In the European region, approximately nine million people are chronically infected with $\mathrm{HCV}$ [2] and according to European Centre for Disease Prevention and Control (ECDC), HCV infection is the most common type of viral hepatitis reported in the European Union (EU) and European Economic Area/European Free Trade Association (EEA/EFTA) countries. In 2009, the overall HCV infection rate of 8.19 per 100,000 population was reported for $26 \mathrm{EU}$ and EEA/EFTA Member States [20]. In 2011, Cornberg et al. [21] reviewed the prevalence of HCV in several countries and the lowest HCV prevalence estimates were from northern European countries, whilst the highest prevalence estimates were from Romania and rural areas in Greece and Italy, as well as portions of Russia.

Chronic HCV infection occurs in approximately 30 million people in the Southeast Asia region [2]. In India the majority of the prevalence studies are based on blood banks data and although several studies estimate a prevalence below $2 \%$ [22], two studies evaluating HCV prevalence specifically in commercial blood donors revealed astonishing rates of 55.3\% and 87.3\% [22-24]. Regarding the Western Pacific region, the large geographical and population distribution profile results in a considerable variability in $\mathrm{HCV}$ prevalence [16]. Although China's estimated HCV prevalence is under 2\% [16], professional blood donors from Hubei Province and from Inner Mongolia Autonomous Region presented much higher rates of $30.1 \%$ and $31.9 \%$, respectively $[25,26]$. According to Sievert et al. [16], China has more HCV-infected persons than all of Europe or the Americas.

2.1. Brazilian Epidemiology. For epidemiological surveillance in Brazil, the Ministry of Health defines the confirmed cases of hepatitis $\mathrm{C}$ as those in which the individual meets the conditions of suspected case and presents positive anti-HCV and detectable HCV-RNA. Therefore, the total number of confirmed cases of hepatitis C in Brazil is 82,041 (Table 2) and $75 \%$ of the cases were registered in individuals between the ages of 30 to 59 years old [5].

Brazil is divided into five geographic regions according to specific characteristics with regard to physical, human,

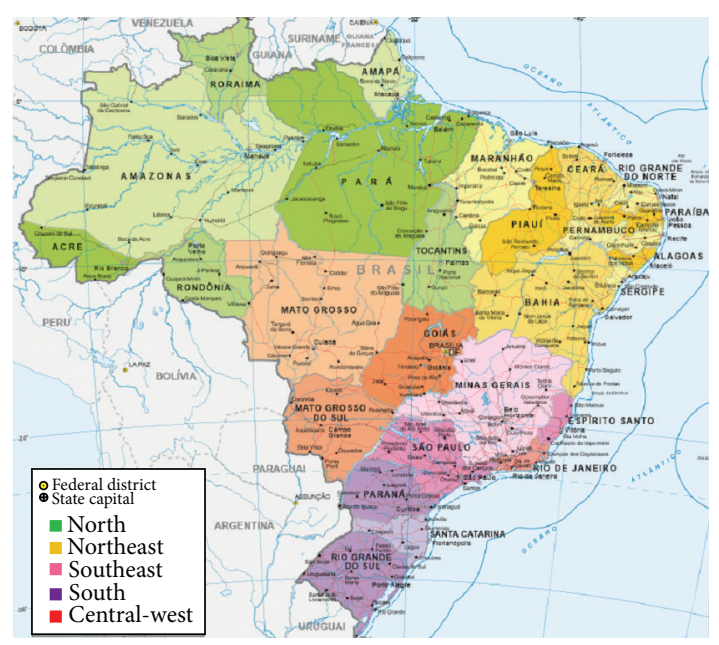

FIGURE 1: Division of the Brazilian territory into five regional geographic areas [4].

economic, and cultural aspects (Figure 1). Therefore, the incidence rates of hepatitis $\mathrm{C}$ are regionally variable. The majority of cases are concentrated in highly populated areas such as the Southeast (67\%) and in the South (22\%) (Figure 2) $[5,6]$. In those regions, the states of São Paulo, localized in the Southeast Region, and Rio Grande do Sul, localized in the South Region, presented the greatest percentages of confirmed cases until 2011 (85\% and 58\%, resp.) [5].

Between blood donors, a variant regional distribution of hepatitis C infection was observed in 2002 [30]. Data obtained from blood donor banks revealed that the highest prevalence was reported in the North Region $(0.62 \%)$, followed by the Northeast $(0.55 \%)$, the South $(0.46 \%)$, the Southeast $(0.43 \%)$, and the West-Center $(0.28 \%)[30,31]$.

The Brazilian Ministry of Health launched a nationwide cross-sectional survey to estimate hepatitis infection prevalence in the urban population of all Brazilian state capitals and the Federal District $[32,33]$. The survey was performed between years 2005 and 2009 and reported an overall prevalence for anti-HCV marker in all capitals of Brazil of $1.38 \%$. Therefore, those areas were classified as having low endemicity of HCV infection [32-35].

The latest epidemiological report on viral hepatitis produced by the Ministry of Health revealed that, in 2011, the overall hepatitis C detection rate in Brazil was 5 per 100,000 population [5]. As shown in Figure 3, the regions with 


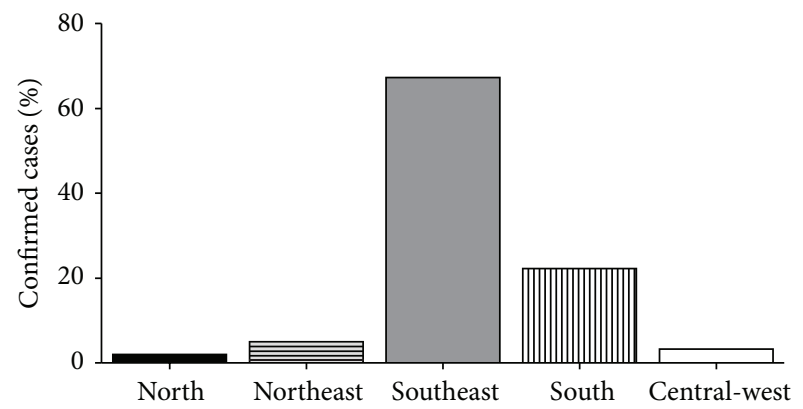

(a)

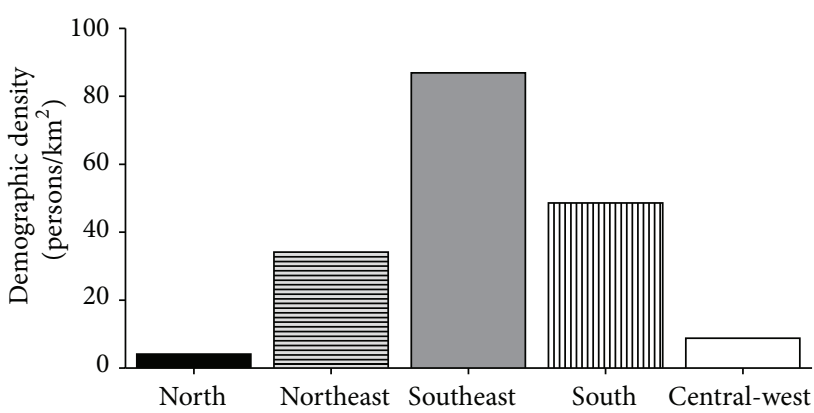

(b)

Figure 2: Brazilian regions: (a) distribution of hepatitis C confirmed cases according to the Ministry of Health [5] and (b) population density according to Brazilian Institute of Geography and Statistics [6].

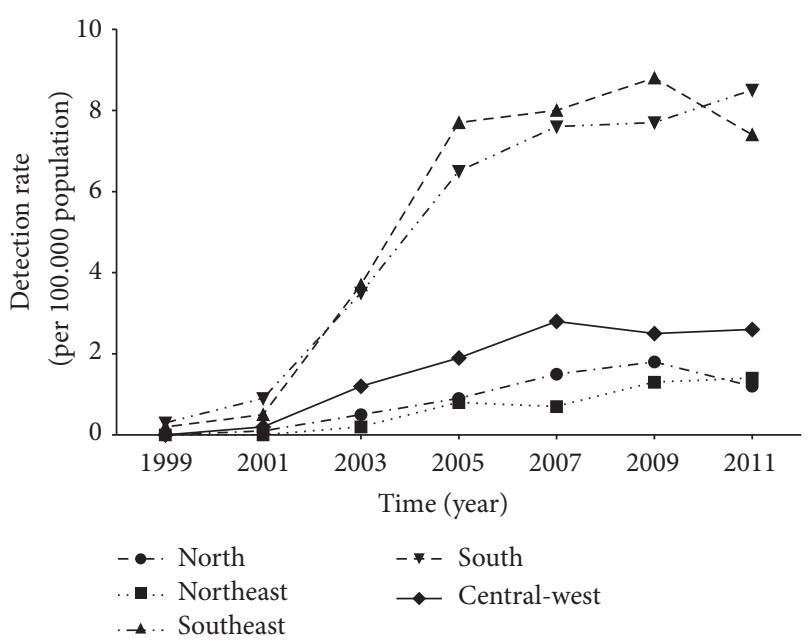

FIGURE 3: Hepatitis $\mathrm{C}$ detection rates in Brazil according to the Ministry of Health [5].

the most elevated detection rates in 2011 were the South and the Southeast ( 8.5 and 7.4 per 100,000 population, resp.). The uneven geographical distribution of HCV in Brazil with the higher number of confirmed cases and detection rates in the regions Southeast and South may be explained by the fact that those are wealthier regions which present highly populated (Figure 2(b)) and urbanized areas with better or easier access to the health system $[6,35,36]$.

\section{Prevention and Control of HCV}

According to WHO, tailored prevention and control strategies for viral hepatitis are necessary because of the differences in the geographic distribution, transmission, diagnosis, and treatment of hepatitis infections among the world [2]. There is no vaccine available for the prevention of $\mathrm{HCV}$ infection; therefore, education, adherence to hygienic standards, and safe injection practices are important strategies in order to prevent HCV transmission $[37,38]$.

Global efforts to reduce hepatitis $C$ burden could benefit from a focus on primary prevention [39] and WHO states that the risk of HCV infection can be reduced by the avoidance of the use of unsafe blood products; use of illicit drugs and sharing of injection equipment; practice of unprotected sex with HCV-infected people; use of unnecessary and unsafe injections; unsafe sharps waste collection and disposal; sharing of sharp personal items possibly contaminated with infected blood and the use of contaminated equipment for tattoos, piercings, and acupuncture [1]. As for secondary and tertiary prevention, WHO recommendation for infected people includes education and counseling regarding care and treatment of the disease; appropriate early medical management of the disease; regular monitoring for early diagnosis of chronic liver disease; and immunization for the prevention of the coinfection with hepatitis A virus (HAV) and hepatitis B virus (HBV) in order to protect the liver [1].

Surveillance for hepatitis $\mathrm{C}$ is important in order to identify $\mathrm{HCV}$-infected people and, therefore, reduce the risks for $\mathrm{HCV}$ transmission and development of chronic liver disease [39-42]. In this regard, the Centers for Disease Control (CDC) in the United States recommends the screening for injection drug users; people on long-term dialysis; children born to HCV-infected women; healthcare and public safety workers after accidents resulting in exposure to HCV positive blood; people who received a blood transfusion or organ transplant before the beginning of blood and organs screening in July 1992; and people who received clotting factor concentrates before the development of more advanced methods for manufacturing those products in 1987 [26, 40].

According to Averhoff and colleagues [43], the absence of effective care and treatment programs in many countries may lead to an increase in HCV-associated morbidity and mortality even when control of HCV transmission is realized. Treatment of hepatitis $C$ is usually based on the combined antiviral therapy with interferon alpha and ribavirin and $\mathrm{HCV}$ is generally considered to be a curable disease. However, there are some limitations for the success of the treatment including the variation in the response to the treatment from person to person, the patient tolerability to the drugs, and the availability of interferon in many countries $[1,2,44]$. In 2011, two HCV NS3/4a protease inhibitors called boceprevir and telaprevir were approved by the FDA and the European Medicines Agency for treatment of patients with chronic 
HCV genotype 1 infection [44, 45]. Despite the encouraging results achieved with the triple therapy with pegylated interferon alpha, ribavirin, and the new protease inhibitors [46-49], treatment of chronic HCV is still a challenge since a significant number of patients are not eligible for this therapy [50].

Overall, eradication of HCV around the world is an extremely challenging task that may be possible through a combination of strategies including the education on infection prevention, clinical and targeted community screening, linkage to disease management, and treatment with new therapeutic regimens [51].

3.1. Prevention and Control of HCV Infection in Brazil. In Brazil, the department called STD, AIDS, and Viral Hepatitis Department is part of the structure of the Ministry of Health's Surveillance Secretariat and intends to reduce HIV/AIDS and viral hepatitis transmission and to promote patients' quality of life [28, 52]. Among the main priorities actions of this department are the prevention and early diagnosis of viral hepatitis infections and HIV; strengthening of the healthcare network and lines of treatment for STDs, viral hepatitis, and AIDS; improvement and development of surveillance, information, and research; and promotion of universal access to medication and condoms, among others [52].

As recommended by WHO [1], prevention of hepatitis $\mathrm{C}$ in Brazil is also focused on primary prevention in order to reduce the risk of disease spreading and on secondary prevention aiming to avoid the progression of the disease in already infected people [53]. According to the Brazilian Ministry of Health's STD, AIDS, and Viral Hepatitis Department, prevention and management strategies should lay emphasis on two generations of people: young people and adults over 45 years old. The main reason regarding the need of special attention to infected adults aging over 45 years is the possible late diagnosis within this population, in which detection of $\mathrm{HCV}$ infection may occur only in advanced stages of the disease particularly because their exposure to HCV is related to blood transfusions performed before blood screening in 1993, injection drug use in the past, and performance of hospital procedures such as hemodialysis. As for the young people population, the risk of exposure to $\mathrm{HCV}$ is through sharing of drug-use equipment (syringes, needles, and pipes) and frequent practice of tattooing and body piercing without attention to sterilization or use of disposable equipment [54].

In order to promote education to the general population about the risks of hepatitis, modes of transmission, and prevention of those diseases, the Brazilian Ministry of Health promotes several public campaigns aiming to increase the awareness of viral hepatitis and to encourage individuals that could have been exposed to hepatitis $C$ to get free diagnostic tests in Counselling and Testing Centres (CTC) [55-58]. The CTC are public health systems that perform diagnostic tests and promote prevention actions for sexually transmitted diseases (STD), viral hepatitis, and HIV/AIDS such as conduction of private or group counseling sessions, education about prevention of those diseases, and also provision of prevention supplies (male and female condoms for the general population, lubricant gel for sex workers and men who have sex with men, and harm reduction kits for people who use drugs) [59].

As a strategy to improve the access to diagnosis of hepatitis $\mathrm{C}$, the Brazilian Ministry of Health started, in 2011, the distribution of HCV rapid tests for HCV screening to the CTC; the expansion of the network of laboratories that performed molecular biology based tests for diagnosis hepatitis C; and the purchase and distribution of viral load and genotyping tests for hepatitis C [60]. It is important to point out that patients who are diagnosed with $\mathrm{HCV}$ infection are referred to specialized services for the proper management and treatment of the disease.

Despite these initiatives, it is worth noting that, in Brazil, about 1,5 million people have been chronically infected with HCV in Brazil and only about 12 thousand people are currently under treatment for hepatitis $\mathrm{C}$, which reflects the large number of individuals without access to diagnosis [54]. Therefore, the expansion of hepatitis $\mathrm{C}$ screening is extremely important, since WHO recognizes early diagnosis as a great opportunity for effective medical support, for prevention of further spread, and also for enabling infected persons to take precautions in order to prevent the transmission of hepatitis to others [2].

Among the programmatic actions for the control of hepatitis C in Brazil is the publication by the Ministry of Health of national protocols and clinical practice guidelines on management and treatment of chronic viral hepatitis $\mathrm{C}$ $[28,29,61]$. Those guidelines provide the recommendations for clinical and therapeutic approaches regarding management of key situations found in routine care of patients with hepatitis C. Initially, the proposed drugs were interferon alpha, pegylated interferon alpha, and ribavirin [28], and more recently, in 2013, boceprevir and telaprevir were also recommended for the treatment of patients chronically infected with HCV genotype 1 with advanced fibrosis [29, 61]. The current major recommendations for hepatitis $C$ treatment in Brazil according to the Ministry of Health are summarized in Table 3.

A national survey about acute hepatitis $C$ was coordinated by the Brazilian Society of Hepatology between the years 2000 and 2008 [62]. The study revealed concern with respect to therapeutic management of the disease since no standard therapeutic regimen could be identified among all studied services. The various treatment regimens reported in the study included conventional or pegylated interferon, which was administered alone or in combination with ribavirin for 16 to 72 weeks, with a sustained virological response (SRV) rate of $60 \%$. Furthermore, the beginning time of treatment was shown to be longer than that recommended with a median of 24 weeks. Therefore, the avoidance of a late onset of treatment was recommended aiming at the achievement of optimized cure rates and reduction of the possible progression to chronic forms of HCV infection.

Regarding the treatment of chronic hepatitis $\mathrm{C}$, Azevedo and colleagues [63] demonstrated SVR rates of approximately $30 \%$ in patients who received either conventional interferon or pegylated interferon in combination with ribavirin. The same SVR rate was shown in another study with patients 
TABLE 3: Recommendations for the treatment of hepatitis C in Brazil according to the Ministry of Health [28, 29].

\begin{tabular}{l}
\hline \multicolumn{1}{c}{ Hepatitis C } \\
\hline Acute \\
\hline (i) Conventional interferon (IFN) monotherapy in a daily dose of induction (alpha-2a at a dose of 6 MUI or \\
alpha-2b at a dose of 5 MUI), subcutaneously (SC), in the first 4 weeks followed by 3 MUI three times per \\
week for 20 weeks (completing 24 weeks of treatment); or \\
(ii) conventional IFN-alpha-2a or alpha-2b, 3 MUI, SC, three times per week, associated to oral ribavirin (RBV) $15 \mathrm{mg} / \mathrm{kg} / \mathrm{day}$ orally \\
for 24 weeks, for those patients at higher risk of intolerance and/or poor treatment adhesion to higher doses of conventional IFN \\
\hline Chronic hepatitis genotype 1 \\
\hline Association of pegylated interferon (PEG-IFN) and RBV for 48 to 72 weeks: \\
PEG-IFN alpha-2a, 180 mcg, SC, 1 time per week associated with oral RBV $15 \mathrm{mg} / \mathrm{kg} / \mathrm{day}$; or \\
PEG-IFN alpha-2b, 1.5 mcg/kg, SC, one time per week, associated with oral RBV 15 mg/kg/day \\
\hline Chronic hepatitis monoinfected with genotype 1 and with advanced fibrosis ${ }^{\mathrm{a}}$ or compensated liver \\
cirrhosis
\end{tabular}

(i) Triple therapy with PEG-IFN alpha, RBV, and telaprevir:

oral telaprevir $750 \mathrm{mg}$, taken 3 times a day (8 hours apart), administered with PEG-IFN alpha and RBV for 4 or 12 weeks

(depending on viral response), followed by a response-guided regimen of either 12 or 36 additional weeks of PEG-IFN alpha and RBV (depending on viral response);

oral telaprevir $750 \mathrm{mg}$, taken 3 times a day (8 hours apart), administered with PEG-IFN alpha and RBV. Therapy initiated with double therapy with PEG-IFN alpha and RBV for 4 weeks, and then addition of telaprevir in a triple therapy for 4 or 12 weeks (depending on viral response), followed by a response-guided regimen of either 12 or 32 additional weeks of double therapy with PEG-IFN alpha and RBV (depending on viral response).

(ii) Triple therapy with PEG-IFN alpha, RBV, and boceprevir' ${ }^{\mathrm{c}}$ : oral boceprevir $800 \mathrm{mg}$ administered orally three times daily (8 hours apart), administered with PEG-IFN alpha and RBV. Therapy initiated with double therapy with PEG-IFN alpha and RBV for 4 weeks and then addition of boceprevir in response-guided regimen of either 8,20 , or 44 additional weeks of triple therapy

Chronic hepatitis genotypes 2 and 3 in the absence of predictors of low sustained virologic response (SVR) ${ }^{\mathrm{d}, \mathrm{e}}$

Combination of conventional IFN and RBV for 24 weeks:

conventional INF alpha-2a or alpha-2b, 3 MUI, SC, 3 times per week, associated with oral RBV $15 \mathrm{mg} / \mathrm{kg} / \mathrm{day}$

Chronic hepatitis genotypes 2 and 3 in the existence of predictors of low $\mathrm{SVR}^{\mathrm{e}}$

Combination of PEG-IFN and RBV for 24 to 48 weeks:

PEG-IFN alpha-2a or PEG-IFN alpha-2b, once a week, SC, associated with oral RBV $15 \mathrm{mg} / \mathrm{kg} / \mathrm{day}$

Chronic hepatitis genotypes 4 and 5

Association of PEG-IFN alpha and RBV for 48 to 72 weeks:

PEG-IFN alpha-2a, $180 \mathrm{mcg}$, SC, 1 time per week associated with oral RBV $15 \mathrm{mg} / \mathrm{kg} / \mathrm{day}$; or

PEG-IFN alpha-2b, $1.5 \mathrm{mcg} / \mathrm{kg}$, SC, one time per week, associated with oral RBV $15 \mathrm{mg} / \mathrm{kg} / \mathrm{day}$

${ }^{a}$ Metavir F3 and F4; or patients with evidence of portal hypertension by endoscopy or imaging tests.

${ }^{\mathrm{b}}$ Patients with compensated liver disease (Child-Pugh score $\leq 6$; class A), with no history of previous decompensation.

${ }^{\mathrm{c}}$ May be considered for patients with advanced fibrosis (Metavir F3 and F4/cirrhosis) according to criteria for individualization of treatment that contraindicates the use of telaprevir for 12 weeks.

${ }^{\mathrm{d}}$ Patients who have predictors of low response to the treatment with conventional INF should receive treatment with PEG-IFN.

${ }^{\mathrm{e}}$ Predictors of low response to the treatment with conventional INF: METAVIR score $\geq$ F3; and/or clinical manifestations of liver cirrhosis; and/or viral load higher than $600,000 \mathrm{UI} / \mathrm{mL}$.

who received only the conventional interferon and ribavirin [64]. A number of studies with hepatitis C genotype 1 patients treated with pegylated interferon in combination with ribavirin revealed SVR rates ranging from approximately 35 to $52 \%[65-68]$.

Most of the studies evaluating the efficacy of the treatment for chronic hepatitis $\mathrm{C}$ in Brazil were performed before the recent introduction of boceprevir and telaprevir for the treatment of patients chronically infected with HCV genotype 1 with advanced fibrosis. Therefore, there is expectation for the possibility of better treatment responses with the use of protease inhibitors in those patients. Further studies will be necessary in order to evaluate the impact of those drugs in the treatment of chronic hepatitis $\mathrm{C}$ in Brazil, especially because HCV genotype 1 is common in the country [5].

In a study on the cost of hepatitis $\mathrm{C}$ treatment for the Brazilian Health System, Blatt and colleagues [69] have demonstrated that the treatment of HCV infection in Brazil is considered expensive taking into account the cost of antiviral drugs and the demands on medical resources. It was estimated that the total direct costs (per patient) of hepatitis $\mathrm{C}$ treatment with interferon plus ribavirin, with pegylated interferon alpha-2a plus ribavirin, and with pegylated interferon alpha-2b plus ribavirin were US $\$ 982.25$, US $\$ 10,658.08$, 
and US $\$ 12,597.63$, respectively. The study revealed that the most expensive element of the total cost of treatment is the antiviral drugs, which are responsible for more than $40 \%$ of the medical costs of interferon plus ribavirin therapy and more than $88 \%$ of pegylated interferon plus ribavirin therapy.

Since there is no vaccine available in order to prevent $\mathrm{HCV}$ infection, the need for improvement of prevention strategies is particularly important regarding hepatitis $C$ control. The estimated absolute numbers of infected individuals shown by the national seroepidemiological survey of hepatitis $\mathrm{A}, \mathrm{B}$, and $\mathrm{C}$ infection indicated the burden of hepatitis $\mathrm{C}$ in the near future [35]. In addition, it is also noteworthy that the risk factors identified within the survey explained less than $50 \%$ of the identified HCV infection cases, a fact that may limit the effective implementation of prevention strategies [35]. The study also pointed out the necessity of improving the strategies for reducing transmission among drug users and nosocomial infection in Brazil. In fact, the rigorous implementation of preventive measures in order to minimize nosocomial transmission in Brazil was also recommended in a national survey on acute hepatitis $\mathrm{C}$ that was coordinated by the Brazilian Society of Hepatology [62].

Prevalence studies may be useful tools not only to verify the impact of the existing hepatitis prevention strategies on the disease epidemiology, but also to create novel disease control strategies. However, Brazilian hepatitis prevalence studies usually present characteristics that may limit their results as of representative value for the whole country: most studies are conducted in restricted areas and not nationwide [70-74] or include only urban areas of the states' capitals such as those observed with the Brazilian National Survey of Viral Hepatitis [32, 34, 35]. Furthermore, most studies are conducted in specific populations, such as blood donors, and not as general population based studies [74-76]. Therefore, further studies should be encouraged so that the real impact of the implemented prevention strategies could be established for the whole country.

\section{Final Disclosures}

The need for improvement of prevention activities is particularly important regarding hepatitis $\mathrm{C}$, since there is no vaccine available in order to prevent HCV infection. In this regard, comprehensive testing strategies must ensure the identification of infected individuals who are at increased risk for spreading hepatitis $\mathrm{C}$ virus.

In addition, public-health measures worldwide should focus on approaches that may increase the awareness of hepatitis $\mathrm{C}$ and also expand the capacity of health systems with respect to surveillance, prevention, treatment, and implementation of effective programmatic actions to control the disease. In this context, implementation of standard precautions in health-care facilities to avoid nosocomial infection and effective public education seem to be the key tools in order to reduce the global impact of HCV infection.

In Brazil, the number of hepatitis $\mathrm{C}$ confirmed cases slightly decreased since 2010 (Table 2), probably as a result of the government's efforts for the improvement of prevention and control of viral hepatitis. Thus, advances in surveillance, diagnosis methods, and disease control programs may have facilitated the identification of cases, treatment of infected patients, and decreasing transmissibility of the virus. On the other hand, it is important to point out that, in Brazil, an additional challenge in order to increase control and management of hepatitis $\mathrm{C}$ is imposed by the vast territorial dimension and the consequent enormous differences regarding culture, population density, income distribution, and health conditions among the five political regions into which the country is divided. The efficacy of government efforts for HCV infection management is still affected by those geographical and socioeconomic aspects, and overcoming these difficulties is an arduous but crucial task for the success in hepatitis $\mathrm{C}$ control.

\section{Conflict of Interests}

The authors declare that there is no conflict of interests regarding the publication of this paper.

\section{References}

[1] World Health Organization, Hepatitis C, Hepatitis C key facts, Fact sheet no. 164, World Health OrganizationMedia Centre, Geneva, Switzerland, 2013, http://www.who.int/mediacentre/ factsheets/fs164/en/index.html.

[2] World Health Organization, Prevention and Control of Viral Hepatitis Infection: Framework for Global Action, World Health Organization, Geneva, Switzerland, 2012, http://www.who.int/ csr/disease/hepatitis/Framework/en/.

[3] N. A. Terrault, "Sexual activity as a risk factor for hepatitis C," Hepatology, vol. 36, no. 5, pp. S99-S105, 2002.

[4] Brazilian Institute of Geography and Statistics, Maps of Brazil: Political Map, IBGE, Brasília, Brazil, 2014, Digital School Geographic Atlas, 2014 (Portuguese), http://atlasescolar.ibge.gov .br/images/atlas/mapas_brasil/brasil_politico.pdf.

[5] Brazil Ministry of Health, 2012 Epidemiological Bulletin on Viral Hepatitis, Health Surveillance Secretariat, Department of STD, AIDS and Viral Hepatitis, Ministry of Health, Brasília, Brazil, 2012 (Portuguese), http://www.aids.gov.br/sites/default/files/ anexos/publicacao/2012/51820/boletim_epidemiol_gico_hepatites_virais_2012_ve_12026.pdf.

[6] Brazilian Institute of Geography and Statistics, 2010 Population Census Summary, IBGE, Brasília, Brazil, 2011 (Portuguese), http://www.censo2010.ibge.gov.br/sinopse/index.php?dados= $10 \& u f=00$.

[7] C. W. Shepard, L. Finelli, and M. J. Alter, "Global epidemiology of hepatitis C virus infection," Lancet Infectious Diseases, vol. 5, no. 9, pp. 558-567, 2005.

[8] World Hepatitis Alliance, Viral Hepatitis: Global Policy, World Hepatitis Alliance, London, UK, 2010, http://www.worldhepatitisalliance.org/en/viral-hepatitis-global-policy-2010.html.

[9] V. Madhava, C. Burgess, and E. Drucker, "Epidemiology of chronic hepatitis C virus infection in sub-Saharan Africa," Lancet Infectious Diseases, vol. 2, no. 5, pp. 293-302, 2002.

[10] H. S. Te and D. M. Jensen, "Epidemiology of hepatitis B and C viruses: a global overview," Clinics in Liver Disease, vol. 14, no. 1, pp. 1-21, 2010. 
[11] Public Health Agency of Canada, Epidemiology of Acute Hepatitis CInfection in Canada-Results from the Enhanced Hepatitis Strain Surveillance System (EHSSS), Public Health Agency of Canada, Ontario, Canada, 2009, http://publications.gc.ca/ collections/collection_2011/aspc-phac/HP40-41-2010-eng.pdf.

[12] Centers for Disease Control and Prevention, Surveillance for Viral Hepatitis-United States, 2010, Centers for Disease Control and Prevention, Atlanta, Ga, USA, 2010, http://www.cdc.gov/ hepatitis/Statistics/2010Surveillance/PDFs/2010HepSurveillanceRpt.pdf.

[13] G. L. Armstrong, A. Wasley, E. P. Simard, G. M. McQuillan, W. L. Kuhnert, and M. J. Alter, "The prevalence of hepatitis C virus infection in the United States, 1999 through 2002," Annals of Internal Medicine, vol. 144, no. 10, pp. 705-714, 2006.

[14] M. Dehesa-Violante and R. Nuñez-Nateras, "Epidemiology of hepatitis virus B and C," Archives of Medical Research, vol. 38, no. 6, pp. 606-611, 2007.

[15] D. Kershenobich, H. A. Razavi, J. F. Sánchez-Avila et al., “Trends and projections of hepatitis $\mathrm{C}$ virus epidemiology in Latin America," Liver International, vol. 31, no. 2, pp. 18-29, 2011.

[16] W. Sievert, I. Altraif, H. A. Razavi et al., "A systematic review of hepatitis C virus epidemiology in Asia, Australia and Egypt," Liver International, vol. 31, no. 2, pp. 61-80, 2011.

[17] F. El-Zanaty and A. Way, Egypt Demographic and Health Survey, 2008, Ministry of Health and Population, Cairo, Egypt, 2009.

[18] D. Lavanchy, "The global burden of hepatitis C," Liver International, vol. 29, no. 1, pp. 74-81, 2009.

[19] C. Frank, M. K. Mohamed, G. T. Strickland et al., "The role of parenteral antischistosomal therapy in the spread of hepatitis $\mathrm{C}$ virus in Egypt," The Lancet, vol. 355, no. 9207, pp. 887-891, 2000.

[20] European Centre for Disease Prevention and Control, Annual Epidemiological Report 2011-Reporting on 2009 Surveillance Data and 2010 Epidemic Intelligence Data, ECDC, Stockholm, Sweden, 2011, http://ecdc.europa.eu/en/publications/Publications/1111_SUR_Annual_Epidemiological_Report_on_Communicable_Diseases_in_Europe.pdf.

[21] M. Cornberg, H. A. Razavi, A. Alberti et al., "A systematic review of hepatitis $C$ virus epidemiology in Europe, Canada and Israel," Liver International, vol. 31, no. 2, pp. 30-60, 2011.

[22] A. Mukhopadhyaya, "Hepatitis C in India," Journal of Biosciences, vol. 33, no. 4, pp. 465-473, 2008.

[23] J. Nandi, V. Bhawalkar, H. Mody, A. Elavia, P. K. Desai, and K. Banerjee, "Detection of HIV-1, HBV and HCV antibodies in blood donors from Surat, Western India [4]," Vox Sanguinis, vol. 67, no. 4, pp. 406-407, 1994.

[24] J. Jha, K. Banerjee, and V. A. Arankalle, "A high prevalence of antibodies to hepatitis $\mathrm{C}$ virus among commercial plasma donors from western India," Journal of Viral Hepatitis, vol. 2, no. 5, pp. 257-260, 1995.

[25] S. Tang, "Seroepidemiological study on hepatitis C virus infection among blood donors from various regions in China," Zhonghua Liu Xing Bing Xue Za Zhi, vol. 14, no. 5, pp. 271-274, 1993.

[26] T. Sy and M. M. Jamal, "Epidemiology of hepatitis C virus (HCV) infection," International Journal of Medical Sciences, vol. 3, no. 2, pp. 41-46, 2006.

[27] K. Mohd Hanafiah, J. Groeger, A. D. Flaxman, and S. T. Wiersma, "Global epidemiology of hepatitis C virus infection: new estimates of age-specific antibody to HCV seroprevalence," Hepatology, vol. 57, no. 4, pp. 1333-1342, 2013.
[28] Brazil Ministry of Health, Clinical Protocol and Therapeutic Guidelines for the Viral Hepatitis $C$ and Coinfections, Health Surveillance Secretariat, Department of STD, AIDS and Viral Hepatitis, Ministry of Health, Brasília, Brazil, 2011 (Portuguese), http://bvsms.saude.gov.br/bvs/publicacoes/protocolos_diretrizes_hepatite_viral_c_coinfeccoes.pdf.

[29] Brazil Ministry of Health, Supplement 2 of the Clinical Protocol and Therapeutic Guidelines for the Viral Hepatitis $C$ and Coinfections-HCV Genotype 1 and Advanced Fibrosis, Health Surveillance Secretariat, Department of STD, AIDS and Viral Hepatitis, Ministry of Health, Brasília, Brazil, 2013 (Portuguese), http://www.aids.gov.br/sites/default/files/anexos/ publicacao/2011/49960/web_suplemento_2_protocolo_hepatite_ c_pdf_98045.pdf.

[30] Brazil Ministry of Health, Manual for Capacity on Epidemiological Surveillance of Viral Hepatitis, Health Surveillance Secretariat, Department of STD, AIDS and Viral Hepatitis, Ministry of Health, Brasília, Brazil, 2008 (Portuguese), http://www.aids.gov.br/sites/default/files/cbve hepatites.pdf.

[31] L. F. Paltanin and E. M. V. Reiche, "Seroprevalence of antihepatitis C virus antibodies among blood donors, Brazil," Revista de Saude Publica, vol. 36, no. 4, pp. 393-399, 2002.

[32] R. A. de Alencar Ximenes, L. M. B. Pereira, C. M. T. Martelli et al., "Methodology of a nationwide cross-sectional survey of prevalence and epidemiological patterns of hepatitis A, B and C infection in Brazil," Cadernos de Saude Publica, vol. 26, no. 9, pp. 1693-1704, 2010.

[33] Brazil Ministry of Health, Epidemiological Bulletin on Viral Hepatitis, Health Surveillance Secretariat, Department of STD, AIDS and Viral Hepatitis, Ministry of Health, Brasília, Brazil, 2011 (Portuguese), http://www.aids.gov.br/sites/default/ files/anexos/publicacao/2011/50073/boletim_hepatites2011_pdf 64874.pdf.

[34] Universidade de Pernambuco, Núcleo de Pós-Graduação, Estudo de prevalência de base populacional das infecções pelos vírus das hepatites $A, B$ E $C$ nas capitais do Brasil, Universidade de Pernambuco, Núcleo de Pós-Graduação, Pernambuco, Brazil, 2010 (Portuguese), http://www.aids.gov.br/sites/ default/files/anexos/publicacao/2010/50071/estudo_prevalencia_hepatites_pdf_26830.pdf.

[35] L. M. M. B. Pereira, C. M. T. Martelli, R. C. Moreira et al., "Prevalence and risk factors of Hepatitis C virus infection in Brazil, 2005 through 2009: a cross-sectional study," BMC Infectious Diseases, vol. 13, no. 1, article 60, 2013.

[36] C. G. Victora, M. L. Barreto, M. Do Carmo Leal et al., "Health conditions and health-policy innovations in Brazil: the way forward," The Lancet, vol. 377, no. 9782, pp. 2042-2053, 2011.

[37] N. Previsani and D. Lavanchy, Hepatitis C, World Health Organization guide on Hepatitis C, WHO/CDS/CSR/LYO/ 2003, World Health Organization, Geneva, Switzerland, 2002, http://www.who.int/csr/disease/hepatitis/whocdscsrlyo2003/ en/index.html.

[38] European Association for the Study of the Liver, "EASL Clinical Practice Guidelines: management of hepatitis C virus infection," Journal of Hepatology, vol. 55, no. 2, pp. 245-264, 2011.

[39] E. E. Mast, M. J. Alter, and H. S. Margolis, "Strategies to prevent and control hepatitis B and $\mathrm{C}$ virus infections: a global perspective," Vaccine, vol. 17, no. 13-14, pp. 1730-1733, 1999.

[40] Centers for Disease Control and Prevention, "Recommendations for prevention and control of hepatitis $\mathrm{C}$ virus (HCV) infection and HCV-related chronic disease," Morbidity and Mortality Weekly Report, vol. 47, RR-19, pp. 1-33, 1998. 
[41] A. do Livramento, C. M. M. de Cordova, C. Spada, and A. Treitinger, "Seroprevalence of hepatitis B and C infection markers among children and adolescents in the Southern Brazilian region," Revista do Instituto de Medicina Tropical de Sao Paulo, vol. 53, no. 1, pp. 13-17, 2011.

[42] N. G. Scaraveli, A. M. Passos, A. R. Voigt et al., "Seroprevalence of hepatitis b and hepatitis C markers in adolescents in Southern Brazil," Cadernos de Saude Publica, vol. 27, no. 4, pp. 753-758, 2011.

[43] F. M. Averhoff, N. Glass, and D. Holtzman, "Global burden of hepatitis C: considerations for healthcare providers in the United States," Clinical Infectious Diseases, vol. 55, pp. S10-S15, 2012.

[44] D. Thomas and F. Zoulim, "New challenges in viral hepatitis," Gut, vol. 61, supplement 1, pp. i1-i5, 2012.

[45] N. M. Dabbouseh and D. M. Jensen, "Future therapies for chronic hepatitis C," Nature Reviews Gastroenterology and Hepatology, vol. 10, no. 5, pp. 268-276, 2013.

[46] I. M. Jacobson, J. G. McHutchison, G. Dusheiko et al., “Telaprevir for previously untreated chronic hepatitis C virus infection," New England Journal of Medicine, vol. 364, no. 25, pp. 24052416, 2011.

[47] F. Poordad, J. McCone Jr., B. R. Bacon et al., "Boceprevir for untreated chronic HCV genotype 1 infection," New England Journal of Medicine, vol. 364, no. 13, pp. 1195-1206, 2011.

[48] B. R. Bacon, S. C. Gordon, E. Lawitz et al., "Boceprevir for previously treated chronic HCV genotype 1 infection," New England Journal of Medicine, vol. 364, no. 13, pp. 1207-1217, 2011.

[49] S. Zeuzem, P. Andreone, S. Pol et al., "Telaprevir for retreatment of HCV infection," New England Journal of Medicine, vol. 364, no. 25, pp. 2417-2428, 2011.

[50] B. Maasoumy, K. Port, A. A. Markova et al., "Eligibility and safety of triple therapy for hepatitis C: lessons learned from the first experience in a real world setting," PLoS ONE, vol. 8, no. 2, Article ID e55285, 2013.

[51] L. M. Hagan and R. F. Schinazi, "Best strategies for global HCV eradication,” Liver International, vol. 33, no. 1, pp. 68-79, 2013.

[52] Brazil Ministry of Health, Departament: The Role of the Department, Health Surveillance Secretariat, Department of STD, AIDS and Viral Hepatitis, Ministry of Health, Brasília, Brazil, 2013, http://www.aids.gov.br/en/pagina/departament.

[53] Brazil Ministry of Health, Hepatitis A, B, C, D and E for Communication Professionals, Health Surveillance Secretariat, Department of STD, AIDS and Viral Hepatitis, Ministry of Health, Brasília, Brazil, 2005 (Portuguese), http://bvsms.saude .gov.br/bvs/publicacoes/hepatites_abcde.pdf.

[54] Brazil Ministry of Health, Hepatites Virais no Brasil: Situação, Ações e Agenda, Health Surveillance Secretariat, Department of STD, AIDS and Viral Hepatitis, Ministry of Health, Brasília, Brazil, 2011 (Portuguese), http://www.aids.gov.br/sites/default/ files/anexos/publicacao/2011/50069/agendahepatites_2011_pdf_ 19532.pdf.

[55] Brazil Ministry of Health, Campaign for the 2011 World Hepatitis Day, Health Surveillance Secretariat, Department of STD, AIDS and Viral Hepatitis, Ministry of Health, Brasília, Brazil, 2011 (Portuguese), http://www.aids.gov.br/en/campanhas/2011/ 51680.

[56] Brazil Ministry of Health, Campanha do Dia Mundial de Luta Contra as Hepatites Virais 2012, Health Surveillance Secretariat, Department of STD, AIDS and Viral Hepatitis, Ministry of Health, Brasília, Brazil, 2012 (Portuguese), http://www.aids.gov.br/campanhas/2012/51811.
[57] Brazil Ministry of Health, A, B, C, D, E of Viral Hepatitis for Health Community Agents, Health Surveillance Secretariat, Department of STD, AIDS and Viral Hepatitis, Ministry of Health, Brasília, Brazil, 2009 (Portuguese), http://www.aids.gov .br/campanhas/2013/54905.

[58] Brazil Ministry of Health, Campaign for the 2013 World HepatItis Day, Health Surveillance Secretariat, Department of STD, AIDS and Viral Hepatitis, Ministry of Health, Brasília, Brazil, 2011 (Portuguese), http://www.aids.gov.br/campanhas/ 2013/54905.

[59] Brazil Ministry of Health, Health Services: Counselling and Testing Centres, Health Surveillance Secretariat, Department of STD, AIDS and Viral Hepatitis, Ministry of Health, Brasília, Brazil, 2013, http://www.aids.gov.br/en/pagina/counsellingand-testing-centres.

[60] Brazil Ministry of Health, National (Unified) Health System Adopts Rapid Tests for Hepatitis B and C: Early Diagnosis Helps Prevent Disease Transmission and Enhances Efficacy of Treatment, Health Surveillance Secretariat, Department of STD, AIDS and Viral Hepatitis, Ministry of Health, Brasília, Brazil, 2011 (Portuguese), http://www.aids.gov.br/noticia/2011/sus_ adota_testes_rapidos_para_hepatites_b_e_c.

[61] Brazil Ministry of Health, Supplement 1 of the Clinical Protocol and Therapeutic Guidelines for the Viral Hepatitis $C$ and Coinfections-Management of Patients Chronically Infected with HCV Genotype 1 and Advanced Fibrosis, Health Surveillance Secretariat, Department of STD, AIDS and Viral Hepatitis, Ministry of Health, Brasília, Brazil, 2013 (Portuguese), http:// www.aids.gov.br/publicacao/2011/protocolo_clinico_e_diretrizes_ terapeuticas_para_hepatite_viral_c_e_coinfeccoes.

[62] A. D. S. P. Ferreira, R. D. M. Perez, M. L. G. Ferraz et al., "Acute hepatitis C in Brazil: results of a national survey," Journal of Medical Virology, vol. 83, no. 10, pp. 1738-1743, 2011.

[63] F. K. S. F. D. Azevedo, C. C. S. F. D. Azevedo, and F. J. D. Souto, "Assessment of the treatment of chronic hepatitis $\mathrm{C}$ in the state of Mato Grosso, central Brazil," Memórias do Instituto Oswaldo Cruz, vol. 107, no. 2, pp. 217-223, 2012.

[64] R. N. Acras, M. L. A. Pedroso, L. C. Caum, J. C. Pisani, H. M. B. S. Amarante, and E. R. Carmes, "The sustained response rates for chronic hepatitis $\mathrm{C}$ patients undergoing therapy with the several interferons and ribavarins supplied by Brazilian's Health Ministry is comparable to those reported in the literature," Arquivos de Gastroenterologia, vol. 41, no. 1, pp. 3-9, 2004.

[65] C. Brandão, A. Barone, F. Carrilho et al., "The results of a randomized trial looking at 24 weeks vs 48 weeks of treatment with peginterferon $\alpha-2 \mathrm{a}(40 \mathrm{kDa})$ and ribavirin combination therapy in patients with chronic hepatitis C genotype 1," Journal of Viral Hepatitis, vol. 13, no. 8, pp. 552-559, 2006.

[66] G. F. Silva, R. J. Polônio, M. I. M. C. Pardini et al., "Using pegylated interferon alfa- $2 \mathrm{~b}$ and ribavirin to treat chronic hepatitis patients infected with hepatitis $C$ virus genotype 1 : are nonresponders and relapsers different populations?" Brazilian Journal of Infectious Diseases, vol. 11, no. 6, pp. 554-560, 2007.

[67] P. R. L. de Almeida, A. A. de Mattos, K. M. Amaral et al., "Treatment of hepatitis $\mathrm{c}$ with peginterferon and ribavirin in a public health program," Hepato-Gastroenterology, vol. 56, no. 89, pp. 223-226, 2009.

[68] J. L. Narciso-Schiavon, L. D. L. Schiavon, R. J. Carvalho-Filho et al., "Gender influence on treatment of chronic hepatitis C genotype 1," Revista da Sociedade Brasileira de Medicina Tropical, vol. 43, no. 3, pp. 217-223, 2010. 
[69] C. R. Blatt, N. L. M. D. C. Bernardo, J. A. Rosa et al., "An estimate of the cost of hepatitis $\mathrm{C}$ treatment for the Brazilian health system," Value in Health Regional Issues, vol. 1, no. 2, pp. 129135, 2012.

[70] A. R. Voigt, M. S. Neto, C. Spada, and A. Treitinger, "Seroprevalence of hepatitis $\mathrm{b}$ and hepatitis $\mathrm{C}$ markers among children and adolescents in the south brazilian region-metropolitan area of Florianópolis, Santa Catarina," Brazilian Journal of Infectious Diseases, vol. 14, no. 1, pp. 60-65, 2010.

[71] M. K. C. de Almeida, K. N. dos Santos, A. A. Fecury et al., "Prevalence of viral hepatitis B and C in riverside communities of the Tucuruí Dam, Pará, Brazil," Journal of Medical Virology, vol. 84, no. 12, pp. 1907-1912, 2012.

[72] A. M. Passos, M. S. Neto, A. Treitinger, and C. Spada, "Seroprevalence of $\mathrm{HBV}$ and $\mathrm{HCV}$ markers among young adult males in the air force in Florianópolis, South Brazil," Brazilian Journal of Pharmaceutical Sciences, vol. 48, no. 2, pp. 257-264, 2012.

[73] J. A. Aquino, K. A. Pegado, L. P. Barros, and L. F. A. Machado, "Seroprevalence of hepatitis B virus and hepatitis C virus infections among individuals in the State of Pará," Revista da Sociedade Brasileira de Medicina Tropical, vol. 41, no. 4, pp. 334337, 2008.

[74] F. B. Garcia, G. D. A. Pereira, P. R. J. Martins, and H. MoraesSouza, "Epidemiological profile of hepatitis $\mathrm{C}$ in blood donors at the Uberaba Regional Blood center," Revista da Sociedade Brasileira de Medicina Tropical, vol. 42, no. 1, pp. 1-4, 2009.

[75] M. C. Nascimento, P. Mayaud, E. C. Sabino, K. L. Torres, and S. Franceschi, "Prevalence of hepatitis B and C serological markers among first-time blood donors in Brazil: a multi-center serosurvey," Journal of Medical Virology, vol. 80, no. 1, pp. 53-57, 2008.

[76] A. F. B. Andrade, M. Oliveira-Silva, S. G. C. Silva, I. J. F. Motta, and C. R. Bonvicino, "Seroprevalence of hepatitis B and C virus markers among blood donors in Rio de Janeiro, Brazil, 19982005," Memorias do Instituto Oswaldo Cruz, vol. 101, no. 6, pp. 673-676, 2006. 


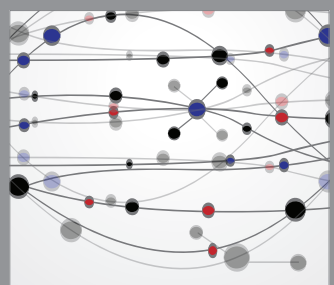

The Scientific World Journal
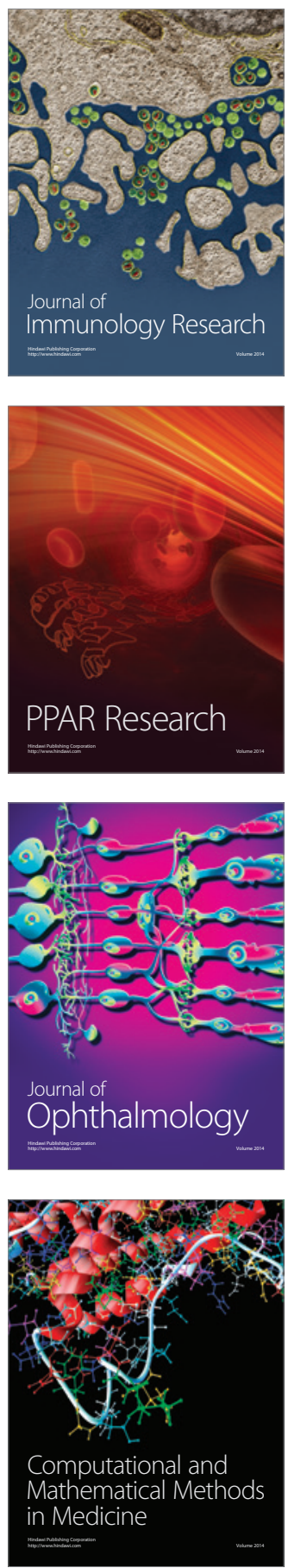

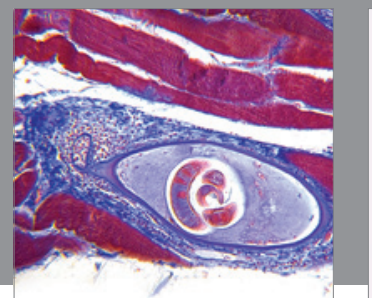

Gastroenterology

Research and Practice
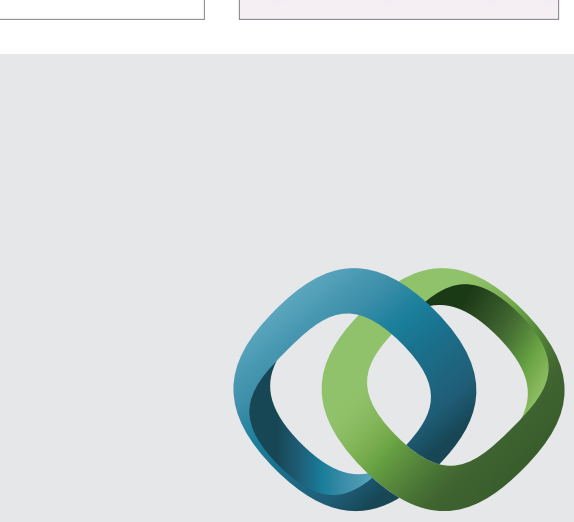

\section{Hindawi}

Submit your manuscripts at

http://www.hindawi.com
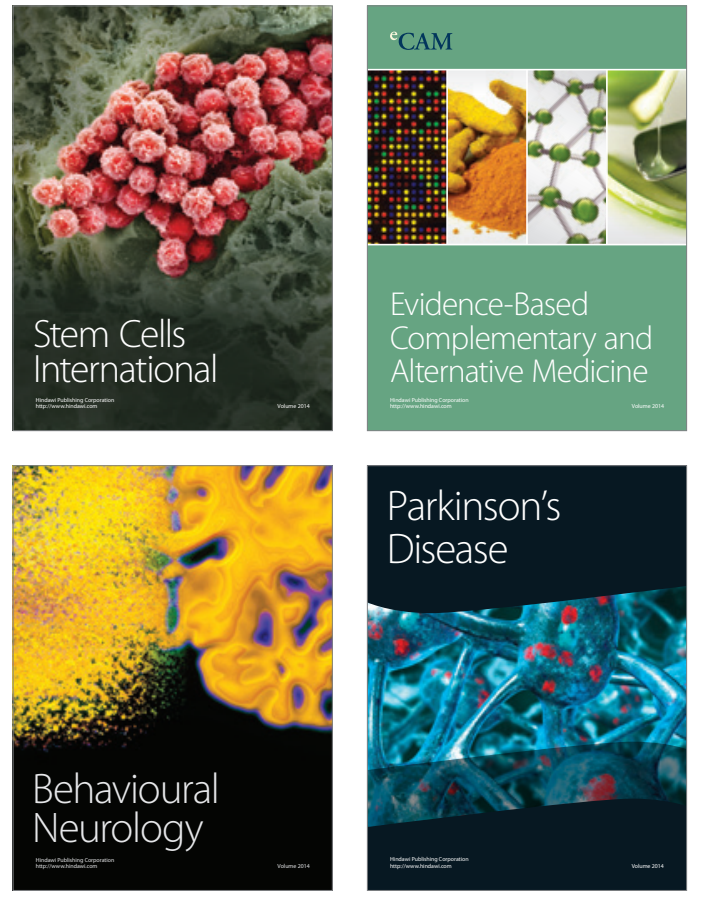
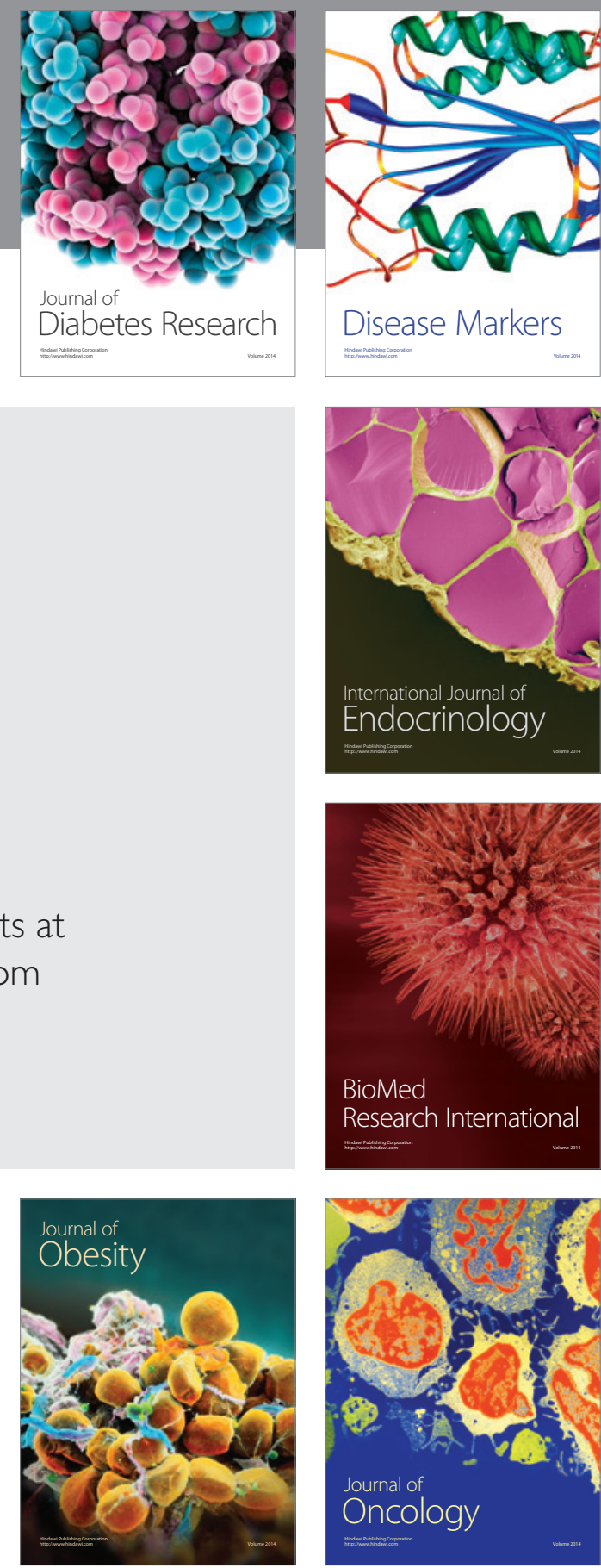

Disease Markers
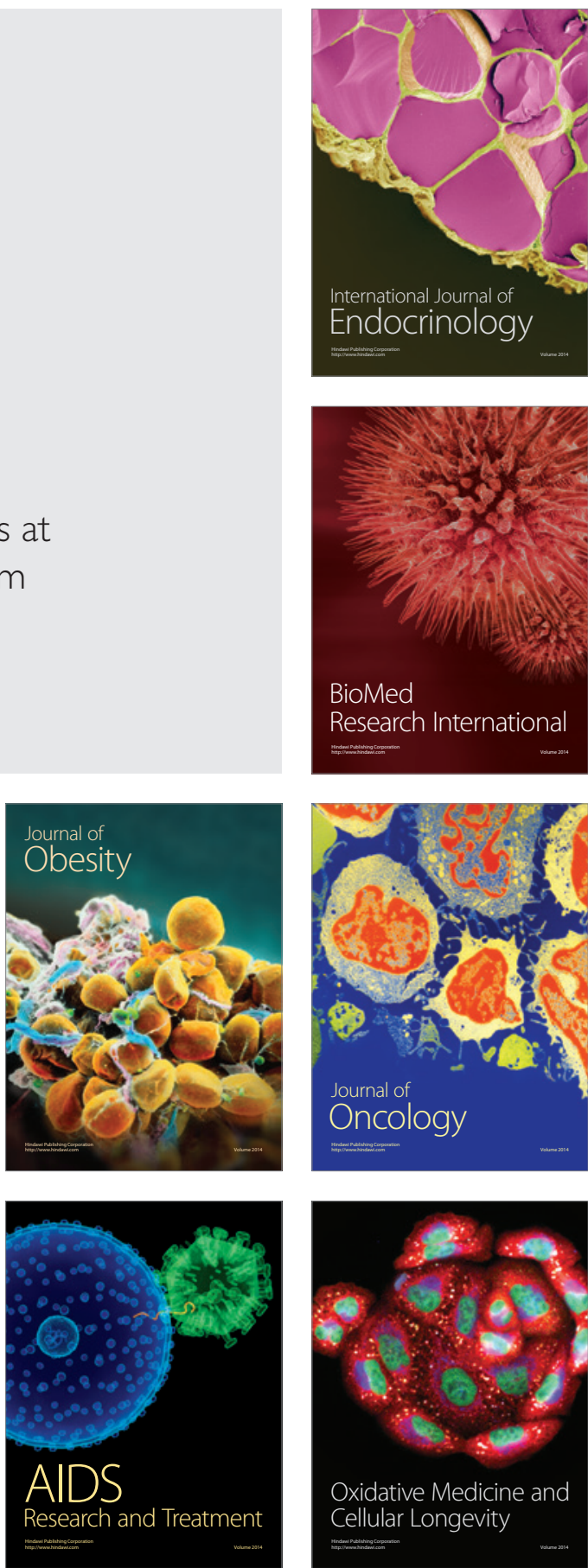